JURNAL ILMIAH ELEKTRONIKA DAN KOMPUTER, Vol.14, No.2, Desember 2021, pp. 224 - 233

p-ISSN : 1907-0012 (print)

e-ISSN : 2714-5417 (online)

http://journal.stekom.ac.id/index.php/elkom

\title{
Implementasi Aplikasi Sistem Peramalan Persedian Barang Menggunakan Metode Single Moving Average Berbasis Web
}

\author{
Eko Siswanto $^{1}$, Eka Satria Wibawa ${ }^{2}$, Zaenal Mustofa ${ }^{3}$ \\ ${ }^{1}$ Sistem Informasi, Universitas Sains Dan Teknologi Komputer \\ J1. Majapahit No.605, e-mail: ekosiswanto@provisi.ac.id \\ ${ }^{2}$ Ekonomi, Universitas Sains Dan Teknologi Komputer \\ J1. Majapahit No 605, e-mail: ekasw@provisi.ac.id \\ ${ }^{3}$ Ilmu KomputerUniversitas Sains Dan Teknologi Komputer \\ J1. Majapahit No.605, e-mail: zm.tofu@gmail.com
}

\section{ARTICLE INFO}

Article history:

Received 31 Oktober 2021

Received in revised form 02 November 2021

Accepted 10 November 2021

Available online 1 Desember 2021

\section{ABSTRACT}

Forecasting is an estimate of future demand based on several forecasting variables based on historical time series or a process of using historical data (past data) that has been owned to use this model and use this model to estimate future conditions.

The Ivori mini market SME group is known to be a mini market that sells daily necessities. The goods provided by the ivori mini market are not focused on only one type of goods, but include all types of goods. Ivori mini market often runs out of stock because there is no inventory planning. The main purpose of making this application is to assist employees in determining inventory planning that must be provided next month. While the method used to make this forecast is a single moving average, one of the time series methods in forecasting. Single Moving Average is a forecasting method that is done by collecting a group of observed values, looking for the average value as a forecast for the future period. The result of this forecasting is to predict the number of sales that will occur in the coming month.

Keywords: Web, Single moving average, Forecasting, Sales.

\section{Latar Belakang}

Peramalan adalah salah satu cara yang dapat digunakan untuk membantu memudahkan pihak manajemen atau keuangan agar dapat membuat keputusan yang baik dalam proses produksi. Misalnya dalam menentukan stock barang yang akan disediakan untuk bulan depan. Apabila tidak terjadi penumpukan barang maka biaya operasional di tempat tersebut dapat diperkirakan dengan matang dan tidak akan terjadi defisit dan kegiatan oprasional menjadi lebih baik. Moving Average (rata-rata bergerak) adalah metode peramalan perataan nilai dengan mengambil sekelompok nilai pengamatan yang kemudian dicari rata-ratanya, lalu menggunakan rata-rata tersebut sebagai ramalan untuk periode berikutnya. Istilah rata-rata bergerak digunakan

Received Oktober 31, 2021; Revised Oktober 02, 2021; Accepted November 10, 2021 
karena setiap kali data observasi baru tersedia maka angka rata-rata yang baru dihitung dan dipergunakan sebagai ramalan.

Dalam proses transaksi mini market invori di Kendal Dusun brangsong, kecamatan brangsong, kabupaten kendal masih manual. Terdapat banyak buku yang tertumpuk untuk pelaporan tiap transaksi yang dilakukan. Hal ini menyebabkan dari pihak karyawan untuk melakukan pengecekan kembali data jika diminta pelaporan oleh pimpinan. Masalah lain yang dihadapi toko ini yaitu seringnya terjadi kehabisan stok untuk barang tertentu karena tidak adanya pencatatan penjualan maupun pencatatan stok yang memadai. Hal ini dapat menyebabkan keuntungan toko tersebut berkurang dan terdapat stok barang tidak laku dalam jumlah yang cukup besar. Sehingga mengakibatkan kerugian yang amat besar. Dengan masalah tersebut, penelitian ini akan membuat aplikasi peramalan penjualan dengan melihat stock barang yang ada di gudang untuk mengetahui dan memperkirakan kejadian pasar dan keuntungan dikemudian hari sehingga meminimalisir adanya kerugian. Untuk mengerjakan penelitian ini, menggunakan Metode Single Moving Average

\section{Tinjauan Pustaka}

2.1 Tinjauan pustaka yang pertama adalah karya tulis dari Adi Putra Sejati pada tahun 2013 dengan judul Pembangunan Perangkat Lunak Inventory Management dengan Menggunakan Metode Peramalan Single Moving Average dan Simple Linear Regression. Dengan menggunakan pengembangan Microsoft Visual FoxPro 9.0 dengan sistem operasi Microsoft Windows 7 Ultimate Edition untuk menghitung inventory management dengan menggunakan dua buah metode peramalan yaitu Simple Linear Regression dan Single Moving Average. Kemudian aplikasi ini diuji dengan menggunakan data riil dari Toserba Laris yang berlokasi di Klaten, Jawa Tengah.

2.2 Tinjuan pustaka yang kedua adalah Rival Zunaidhi, Wahyu S. J. Saputra dan Ni Ketut Sari pada tahun 2012 dengan judul Aplikasi Peramalan Penjualan Menggunakan Metode Regresi Linier. Dari aplikasi peramalan penjualan ini akan didapatkan hasil dari peramalan penjualan pada hari yang akan datang dan hasil standart error estimasi peramalan. Perhitungan dari hasil tersebut akan dibandingkan dengan perhitungan dalam microsoft excel. Data diperoleh dari informasi penjualan air Aquaky pada perusahaan CV. Jaya Hikmah Tulungagung Jawa Timur.

2.3 Peramalan merupakan aktivitas fungsi bisnis yang memperkirakan penjualan dan penggunaan produk sehingga produk-produk itu dapat dibuat dalam kuantitas yang tepat. Menurut Gaspersz (2014) peramalan merupakan dugaan terhadap permintaan yang akan datang berdasarkan pada beberapa variabel peramal, sering berdasarkan data deret waktu historis. Peramalan menggunakan teknik-teknik peramalan yang bersifat formal maupun informal.

2.4 Referensi dari Subagyo Pangestu, 2013, Forecasting Konsep dan Aplikasi Moving average merupakan teknik forecasting berdasarkan rata-rata bergerakdari nilai-nilai masa lalu, misalkan rata-rata bergerak 3 tahunan, 4 bulanan, 5 mingguan, dan lain-lain. Akan tetapi teknik ini tidak disarankan untuk data time series yang menunjukkan adanya pengaruh trend dan musiman. Moving average terbagi menjadi Single Moving Average dan Double Moving Average. Single Moving Average mempunyai dua sifat khusus

Untuk membuat prakiraan, memerlukan data historis selama jangka waktu tertentu. Semakin panjang jangka waktu perata, akan menghasilkan prakiraan yang semakin halus. Rumus yang digunakan:

Implementasi Aplikasi Sistem Peramalan Persedian Barang Menggunakan Metode Single Moving Average Berbasis Web (Eko Siswanto) 


$$
S_{t+1}=\frac{\mathrm{X}_{1}+\mathrm{X}_{t-1}+\cdots+\mathrm{X}_{t-n+1}}{\mathrm{n}}
$$

Keterangan:

$\mathrm{St}+1$ : forecasting untuk periode ke $\mathrm{t}+1$

$\mathrm{Xn}$ : data pada periode $\mathrm{t}$

n : jangka waktu moving average

Variabel $\mathrm{n}$ dapat diisi angka sesuai dengan keinginan dari pengguna aplikasi. Istilah Rata-rata Bergerak digunakan karena setiap muncul nilai observasi baru, nilai rata-rata baru dapat dihitung dengan membuang nilai observasi yang paling tua dan memasukkan nilai observasi atau data yang terbaru.

Untuk mengetahui tingkat "ketepatan" metode tersebut, maka nilai kesalahan atau error dapat dihitung menggunakan metode Deviasi Absolut Rerata / Mean Absolute Deviation (MAD). Nilai penyimpangan data penjualan di bulan ke-n dengan forecastingyang telah dilakukan sebelumnya, akan dihitung dan dilihat rata-ratanya. Nilai kesalahan tidak diperhatikan tanda positif dan tanda negatifnya. Artinya, penyimpangan atau kesalahan akan dirubah menjadi nilai absolut. Untuk menghitung eror atau nilai kesalahan dari forecasting, yang perlu dilakukan adalah mengambil data aktual yang dikurangi oleh data forecasting yang telah dilakukan sebelumnya.

Niainya bisa plus maupun minus. Setelah didapatkan nilai erornya, nilai-nilai kesalahan tersebut dapat dirata-rata. Rumus yang digunakan untuk merata-rata nilai kesalahan:

$$
M A D=\frac{|\Sigma F|}{\mathrm{n}}
$$

Keterangan:

MAD : rata-rata kesalahan

$\mathrm{F}$ : jumlah / total kesalahan

$\mathrm{n}$ : jumlah data

\subsection{Pengertian PHP (Hypertext Preprocessor)}

PHP adalah bahasa script yang dapat ditanamkan atau disisipkan ke dalam HTML, PHP banyak dipakai untuk membuat program situs web dinamis. PHP sering juga digunakan untuk membangun sebuah CMS. PHP adalah bahasa pemrograman script server-side yang didesain untuk pengembangan web. Disebut bahasa pemrograman server side karena PHP diproses pada komputer server. Hal ini berbeda dibandingkan dengan bahasa pemrograman client-side seperti JavaScript yang diproses pada web browser (client) (Madiun, 2016)

2.6 MySQL adalah sebuah perangkat lunak sistem manajemen basis data SQL(database management system) atau DBMS yang multithread, multi-user, dengan sekitar 6 juta instalasi diseluruh dunia. MySQL merupakan perangkat lunak (software) gratis dibawah lisensi GPL (GNU General Publicc License) (Murya, 2014).

2.7 Pengertian Dreamweaver CS6 merupakan suatu perangkat lunak web editor keluaran Adobe System yang digunakan untuk membangun dan mendesain suatu website dengan fitur-fitur yang menarik dan kemudahan dalam penggunaannya".

2.8 Dreamweaver CS6 tergabung dalam paket Adobe Creative Suite (CS) yang di dalamnya terdapat paket desain grafis, video editing, dan pengembangan web aplikasi. Pada Dreamweaver CS6 terdapat beberapa fitur baru dari versi sebelumnya seperti :

Fluid Grid Layout yang dapat mengatur multi halaman web dengan mudah.

JURNAL ILMIAH ELEKTRONIKA DAN KOMPUTER Vol. 14, No. 2, Desember 2021: $224-243$ 
Web Fonts Manager manajemen yang memungkinkan Anda untuk menggunakan font yang tersedia di web server. CSS Style Panel tambahan untuk membuat grafis seperti bayangan pada elemen tertentu, gradient, membuat sudut oval dan lain sebagainya. CSS Transitions spesial efek pada elemen, Phone GAP memungkinkan Anda untuk membangun aplikasi smartphone menjadi lebih mudah dari sebelumnya.Jadi, Dreamweaver CS6 adalah program untuk membuat website dan Adobe yang paling banyak digunakan saat ini oleh para pengembang website karena program ini canggih namun tetap mudah digunakan (Sadeli, 2013).

2.9 Pengertian phpMyAdmin adalah tools yang dapat digunakan dengan mudah untuk memanajemen database MySQL secara visual dan Server MySQl, sehingga kita tidak perlu lagi harus menulis query SQL setiap akan melakukan perintah operasi database". Tools ini cukup populer, Anda dapat mendapatkan fasilitas ini ketika menginstal paket triad phpMyAdmin, karena termasuk dalam xampp yang sudah di install (Nugroho, 2013).

\subsection{Pengertian XAMPP}

XAMPP adalah paket program web lengkap yang dapat Anda pakai untuk belajar pemrograman web, khususnya PHP dan MySQL (Nugroho, 2013).

\subsection{Pengertian Berbasis Web}

Berbasis Web merupakan perangkat lunak yang dapat diakses dengan menggunakan browser (Sukamto \& Shalahuddin, 2013).

\section{Metode Penelitian}

Metode penelitian yang dilakukan dalam penelitian ini adalah menggunakan metode penelitian dan pengembangan (Research \& Development) dengan metode pengembangan sistem Prototyping untuk menghasilkan produk dalam bentuk Prototype. Sebuah Prototype akan memberikan sebuah gambaran tentang cara kerja sistem yang akan berfungsi dalam bentuk lengkapnya.

Menurut Sugiyono (2014) ada langkah pelaksanaan strategi penelitian dan pengembangan yang dilakukan untuk menghasilkan produk tertentu untuk menguji keefektifan produk yang dimaksud.

Adapun langkah-langkahpenelitiandanpengembanganadasepuluhlangkahsebagaiberikut: (1)

Potensidanmasalah, (2) Pengumpulan data, (3) Desainproduk, (4) Validasidesain, (5) Revisidesain, (6) Ujicobaproduk, (7) Revisiproduk, (8) Ujicobapemakaian, (9) Revisiproduk, dan (10) Produksi massal.

Adapun bagan langkah-langkah penelitiannya seperti ditunjukkan pada gambar berikut :

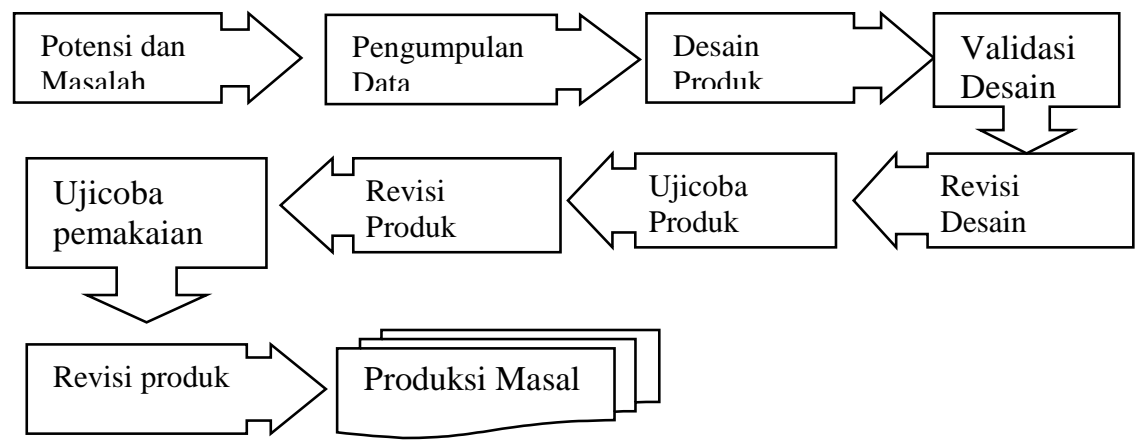

Gambar Bagan Alur Model Pengembangan R\&D

(Sumber :Sugiyono, 2014)

$\overline{\text { Implementasi Aplikasi Sistem Peramalan Persedian Barang Menggunakan Metode Single Moving }}$ Average Berbasis Web (Eko Siswanto) 
Metode penelitian yang digunakan menggunakan sembilan tahap langkah penelitian yaitu:

1. Potensi dan masalah

Penelitian berawal dari adanya potensi atau masalah. Potensi adalah segala sesuatu yang bila didayagunakan akan memiliki nilai tambah.

2. Pengumpulan data

Setelah potensi dan masalah dapat ditunjukkan secara factual dan up to date, selanjutnya perlu dikumpulkan berbagai informasi yag dapat digunakan sebagai bahan untuk perencanaan produk tertentu yang diharapkan dapat mengatasi masalah tersebut. Metode yang akan digunakan untuk penelitian tergantung permasalahan dan ketelitian tujuan yang ingin dicapai.

3. Desain produk

Produk yang dihasilkan dalam penelitian research and development bermacammacam. Untuk menghasilkan sistem kerja baru maka peneliti harus membuat rancangan kerja baru yang dibuat berdasarkan penilaian terhadap system kerja lama, sehingga dapat ditemukan kelemahan-kelemahan terhadap system tersebut.

4. Validasi desain

Validasi desain merupakan proses kegiatan untuk menilai apakah rancangan produk, dalam hal ini system kerja baru secara rasional akan lebih efektif dari yang lama. Dikatakan secara rasional karena validasi disini masih bersifat penilaian berdasarkan pemikiran rasional, belum merupakan fakta dilapangan.

5. Revisi desain

Setelah desain produk divalidasi melalui diskusi dengan para pakar dan ahli lainnya, selanjutnya dapat diketahui kelemahannya. Kelemahan tersebut selanjutnya dicoba untuk dikurangi dengan cara memperbaiki desain. Yang bertugas memperbaiki desain adalah peneliti yang hendak menghasilkan produk tersebut.

6. Uji coba produk

Uji coba produk dapat dilakukan melalui eksperimen, yaitu membandingkan efektifitas dan efisiensi keadaan sebelum dan sesudah memakai sistem baru (beforeafter) atau dengan membandingkan dengan kelompok yang tetap menggunakan sistem lama.

7. Revisi Produk

Setelah melewati uji coba maka akan dapat diketahui kelemahan yang terdapat pada pengembangan yang peneliti lakukan. Dengan mempelajari kelemahan pada produk yang dihasilkan maka peneliti akan melakukan revisi produk, dengan cara mengumpulkan data dari peserta yang diuji coba. Dari data yang didapat akan mempermudah peneliti dalam mengadakan revisi produk.

8. Uji Coba Pemakaian

Pada tahap uji coba pemakaian peneliti tetap harus mempelajari kemungkinankemungkinan adanya kekurangan yang ada. Setelah uji coba mendapatkan hasil maka peneliti harus mengkaji hambatan yang muncul guna memperbaiki produk.

9. Revisi Produk

Tahap ini dilakukan apabila dalam penggunaan produk dalam kondisi yang sebenarnya masih terdapat kekurangan. 


\section{Hasil Dan pembahasan}

\section{Halaman Login}

Halaman ini berfungsi untuk pengamanan aplikasi.

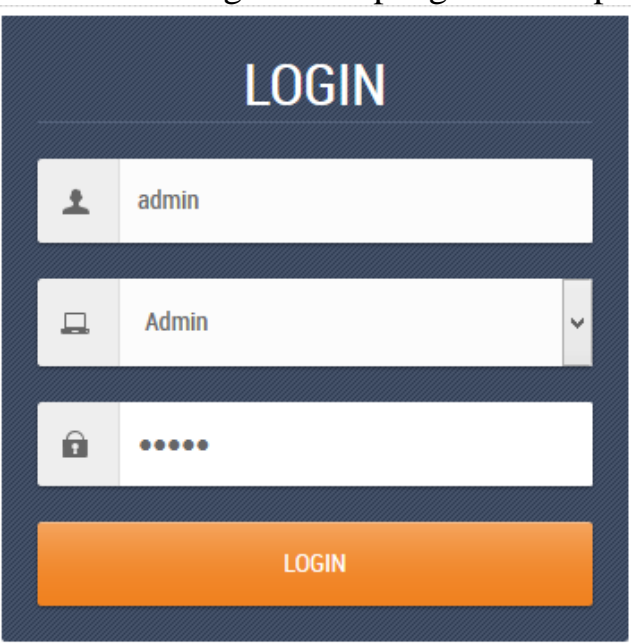

Gambar 1 Halaman Login

Keterangan :

a. Masukkan ID User Dan Level.

b. Masukan Sandi yang sesuai dengan ID User.

c. Tekan tombol Masuk untuk masuk ke form menu utama.

\section{Halaman Menu}

Halaman ini akan tampil jika proses masuk sistem berhasil dilakukan. Fungsi halaman ini sebagai panel Sistem Informasi Persediaan Dan Penjualan Pada Ud. Adi Arya Collection Menggunakan Metode Moving Average.

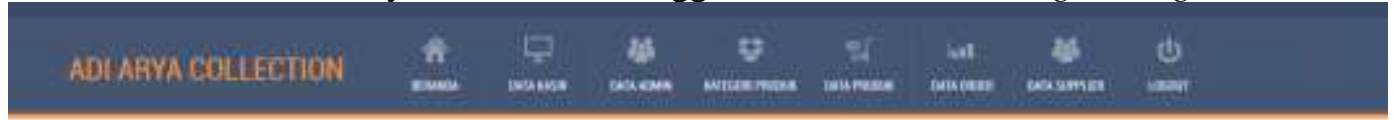

Selamat Datang Administrator di UD.Adi Arya Collection

GLALESEG WBODK

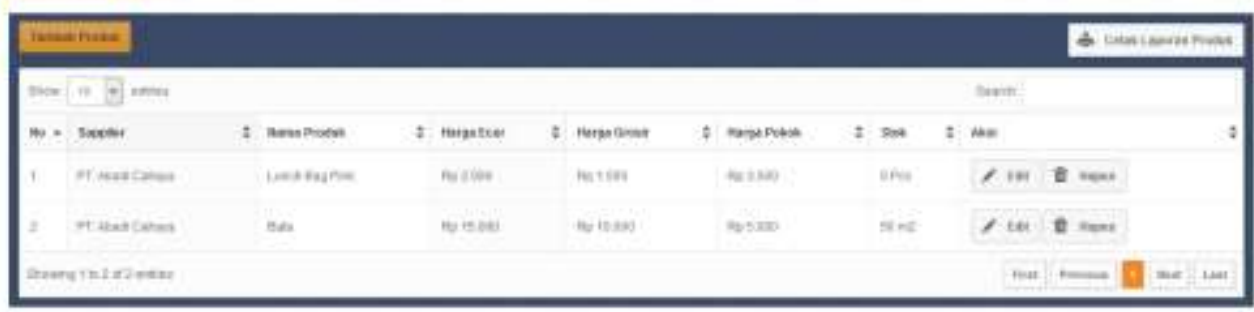

Gambar 2 Halaman Menu Utama

Form ini berisikan menu-menu yang menjadi menu awal dan terdapat fasilitas sistem-sistem yang dapat digunakan oleh pengguna seperti Master, Proses Transaksi, Laporan dll. 
Form Data User

Halaman ini berfungsi untuk mengisi data pemakai sistem.

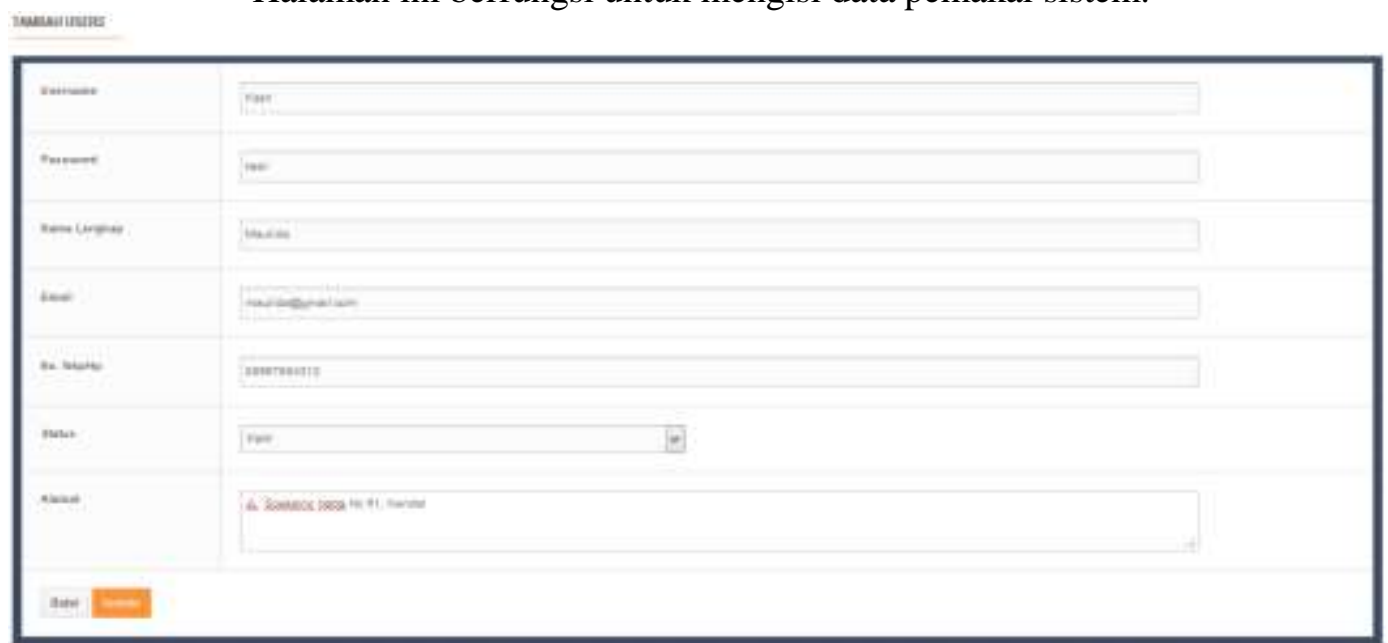

Gambar 3 Halaman Form Pemakai

Keterangan:

a. Klik Tombol Tambah User untuk memulai memasukan data user.

b. Masukan username, password, nama lengkap, email, no telp, status dan alamat.

c. Tombol Update untuk menyimpan data pemakai.

d. Tombol Batal untuk membatalkan pengisian data.

\section{Halaman Data Suplier}

TaMeus suphteg Phoouk

Halaman ini digunakan untuk menginputkan data Suplier.

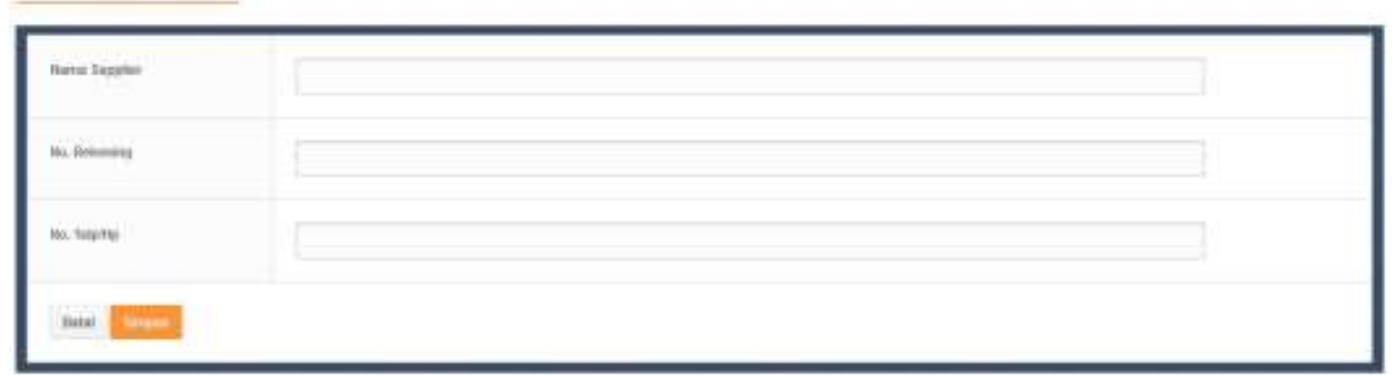

Gambar 4 Halaman Form Data Suplier

Keterangan :

a. Klik Tombol Tambah Suplier untuk memulai memasukan data suplier

b. Masukan Nama suplier, No Rekening, Dan no telp.

c. Tombol Update untuk menyimpan data pemakai.

d. Tombol Batal untuk membatalkan pengisian data.

\section{Halaman Data Produk}

Halaman ini digunakan untuk menginputkan data produk.

JURNAL ILMIAH ELEKTRONIKA DAN KOMPUTER Vol. 14, No. 2, Desember 2021 : $224-243$ 


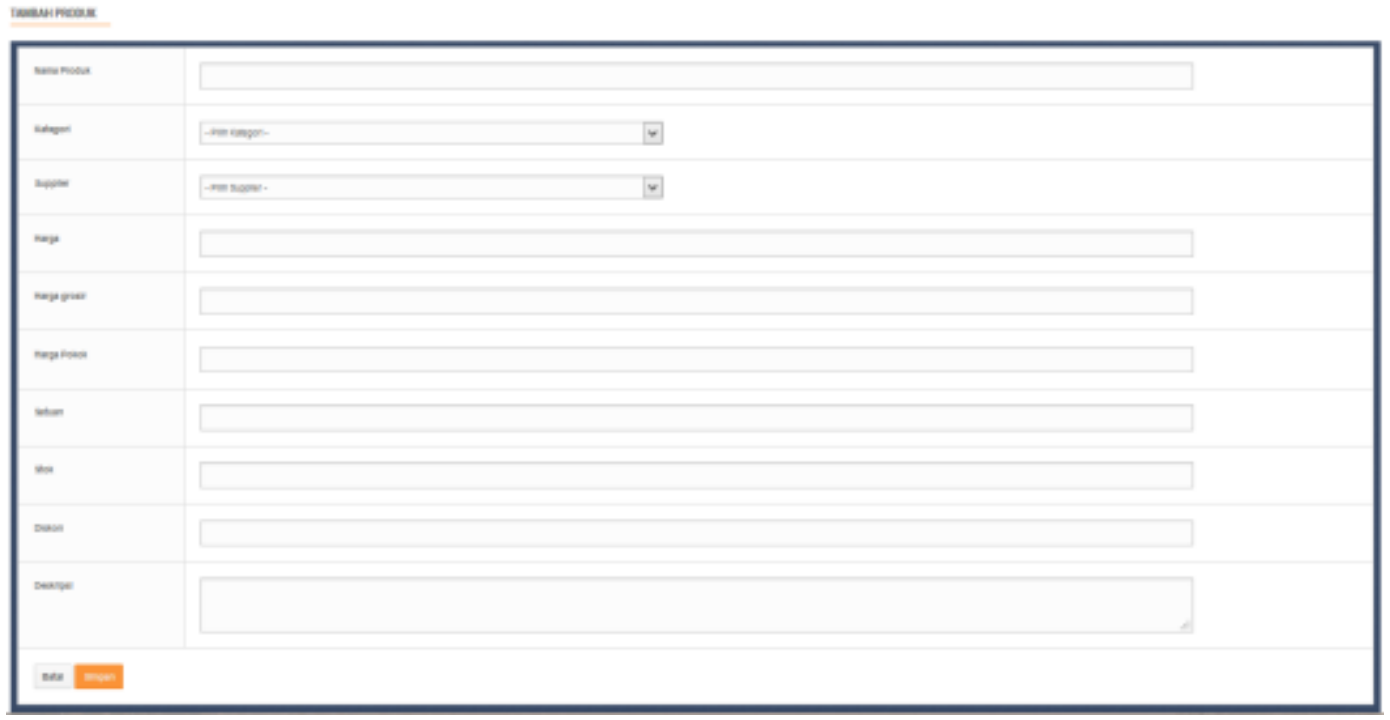

Gambar 5 Halaman Form Data Produk

Keterangan :

a. Klik Tombol Tambah Produk untuk memulai memasukan data suplier.

b. Masukan Nama produk, Kategori, Suplier, Harga, Harga Grosir, Harga

Pokok, Satuan, Stok, Diskon, Dan Deskripsi.

c. Tombol Simpan untuk menyimpan data produk.

d. Tombol Batal untuk membatalkan pengisian data.

\section{Halaman Data Kategori}

Halaman ini digunakan untuk menginputkan Kategori Produk.

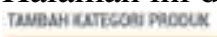

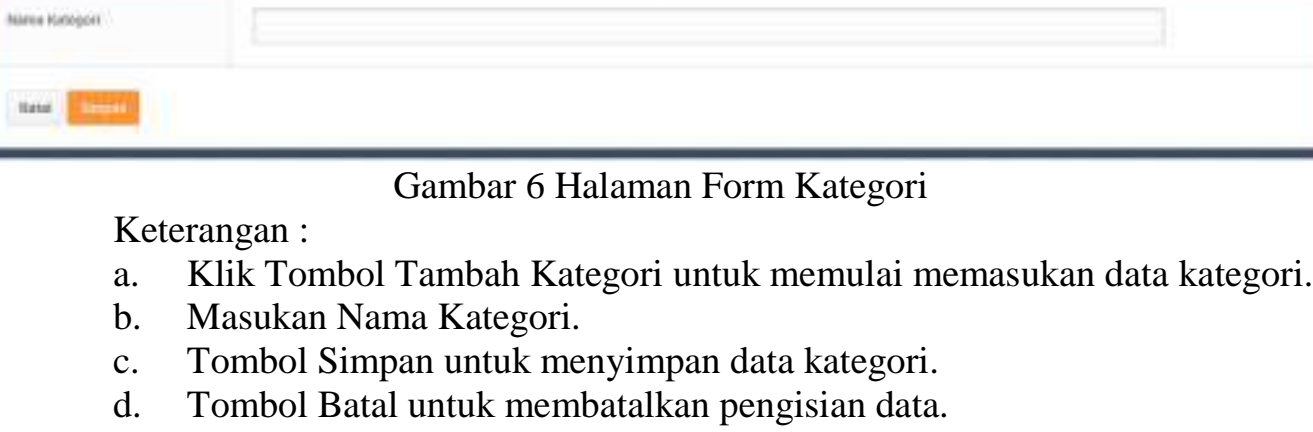

Gambar 6 Halaman Form Kategori

Keterangan :

a. Klik Tombol Tambah Kategori untuk memulai memasukan data kategori.

b. Masukan Nama Kategori.

c. Tombol Simpan untuk menyimpan data kategori.

d. Tombol Batal untuk membatalkan pengisian data.

\section{Halaman Data Penjualan}

Halaman ini digunakan untuk menginputkan Data Penjualan. 
DEFTR PFOCOK YANG SLDAH NNU ORCER.

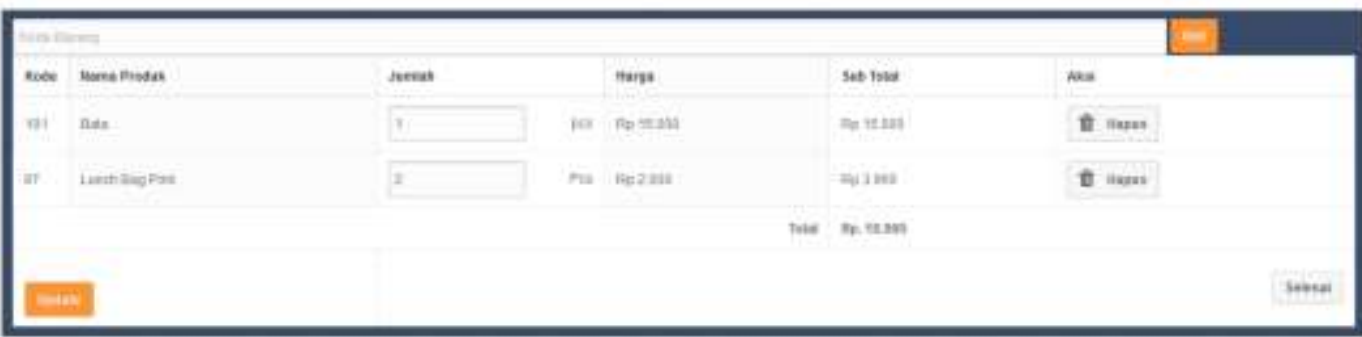

Gambar 7 Halaman Form Penjualan

Keterangan :

a. Masukan Kode Barang kemudian klik tombol beli.

b. Isi jumlah kemudian klik tombol update untuk memperbarui total harga.

c. Tombol hapus untuk menghapus daftar produk.

d. Tombol selesai untuk menyimpan data penjualan.

\section{Laporan Data Produk}

UD.ADI ARYA COLLECTION

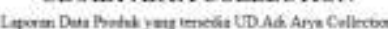

\begin{tabular}{|c|c|c|c|c|c|c|}
\hline $\mathrm{No}$ & Nana Prodak. & Katregeri & Aarn & Soak & Dithas & Nama Sevplier \\
\hline 1 & Pata & Chash & rooes & 100 & $\approx$ & Dr Ahat Caph \\
\hline 2 & 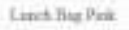 & $\ln a \mid \ln \in(1 . B)$ & 2000 & 100 & 14 & Wt. Alud Conge \\
\hline
\end{tabular}

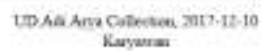

Gambar 8 Laporan Data Produk

Keterangan :

Halaman ini digunakan untuk melihat laporan produk pada UD. Adi Arya

Collection .

\section{Laporan Data Penjualan}

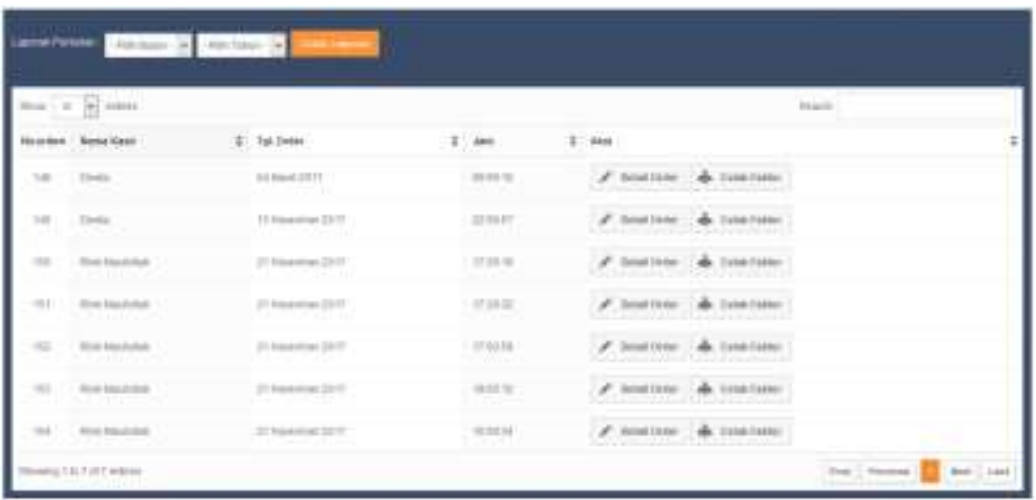

Gambar 9 Laporan Data Penjualan

Keterangan :

Halaman ini digunakan untuk melihat laporan penjualan pada UD. Adi Arya Collection . 


\subsection{Kesimpulan}

Dari hasil pengujian tersebut dapat ditarik kesimpulan bahwa dengan adanya sistem peramalan persediaan barang menggunakan metode moving average dapat digunakan sebagai sistem pengambilan keputusan bagi manager dalam menentukan jumlah persediaan barang untuk periode kedepanya.

\subsection{Saran}

Adapun saran yang dapat dikemukakan oleh penulis yaitu penelitian berikutnya menggunakan metode peramalan lain yang nilai akurasinya mendekati $100 \%$ dari nilai aktual dengan tujuan meminimalisir kerugian perusahaan akibat proses persediaan barang yang tidak akurat

\section{Daftar Pustaka}

Adra, Sejatiiput, 2013, "Pembangunan Perangkat Lunak Inventory Mangementdengan Menggunakan Metode Peramalan Single Moving Average dan SimpleLinear Regression".

Akbar, Agung. S, 2014, "Penerapan Metode Single Moving Average Dan Exponential Smoothing Dalam PeramalanPermintaan Produk Meubel JenisCoffee Table Pada Java Furniture Klaten" Fakultas Ekonomi, Universitas Sebelas Maret Surakarta.

Pengestu, Subagyo, 2013, “Forecasting Konsep dan Aplikasi”, Y, BBPE-Yogyakarta.

Kadir Abdul, 2013; "Pengenalan Sistem Informasi Edisi Revisi”, Yogyakarta: Andi.

Madiun, M., 2016; "Pemrograman PHP dan My SQL untuk Pemula", Yogyakarta: CV. Andi Offset.

Murya, 2014; “Project PHP Membuat Web Site Buku Digital”, Jakarta: Jasakom

Nugroho Bunafit, 2013; "Dasar Pemograman Web PHP - MySQL dengan Dreamweaver", Yogyakarta : Gava Media Maxikom.

Sadeli Muhammad, 2013; "Dreamweaver CS6 Untuk Orang Awam", Palembang:

Sugiyono, 2014; "Metode Penelitian Kuantitatif, Kualitatif, dan R\&D", Bandung: Alfabeta .

Sukamto, R,A., \& Shalahuddin, M., 2011; “Modul Pembelajaran Rekayasa Perangkat Lunak", Bandung.

Implementasi Aplikasi Sistem Peramalan Persedian Barang Menggunakan Metode Single Moving 